\title{
OPTIMASI GEOMETRI BERDARASKAN GAYA-GAYA DALAM PADA JEMBATAN PELENGKUNG BETON
}

\author{
Almulianur ${ }^{1}$, Akhmad Aminullah², Muslikh ${ }^{3}$ \\ 1,2,3 Departemen Teknik Sipil dan Lingkungan, Fakultas Teknik, Universitas Gadjah Mada \\ Emil :almulianursipil@gmail.com
}

\begin{abstract}
This study discusses geometricoptimization based on internal forces that occur on concrete arch bridges. Geometric optimization is viewed from the use of the ratio between the height to the length of arch. Optimum ratio based on the internal forces that occur on concrete arch bridge. The ratio between the height and the length of arch are made on the concrete arch bridge with the span of $150 \mathrm{~m}$, variation of the ratio performed 1:2 to 1: 8 with interval of 0.25. Modeling of concrete arch bridge was made on softwere SAP 2000 with 25 models due to the difference of ratio interval variation. Based on the results of internal forces with variation of the ratio, the results for the most optimum geometry are 1: 4 to $1: 7,25$.
\end{abstract}

Keywords: concrete arch bridge, geometry,optimization, ratio

\begin{abstract}
ABSTRAK
Pada kajian ini membahas tentang optimasi geometri berdasarkan gaya-gaya dalam yang terjadi pada jembatan pelengkung beton. Optimasi geometri dilihat daripenggunaan rasio antara tinggi pelengkung terhadap panjang pelengkung. Rasio yang paling optimum berdasarkan gaya-gaya yang terjadi pada jembatan pelengkung beton. Rasio antara tinggi pelengkung dan panjang pelengkung akan dilakukan pada jembatan pelengkung beton dengan bentang $150 \mathrm{~m}$. variasi rasio dilakukan antara $1: 2$ sampai $1: 8$ dengan interval 0.25 . Pemodelan jembatan pelengkung beton dilakukan pada softwere sap 2000 dengan 25 model akibat perbedaan variasi interval rasio. Berdasarkan hasil gaya-gaya dalam dengan variasi rasio didapatkan hasil untuk geometri yang paling optimum berada antara rasio $1: 4$ sampai $1: 7,25$.
\end{abstract}

Kata kunci: jembatan pelengkung beton geometri, optimasi, rasio

\section{PENDAHULUAN}

Jembatan pelengkung adalah jembatan dengan struktur setengah lingkaran dimana pada kedua ujungnya bertumpu pada abutmen. Ketika menahan beban akibat berat sendiri dan beban lalu lintas, setiap bagian pelengkung menerima gaya tekan, karena alasan itulah jembatan pelengkung harus terdiri dari material yang tahan terhadap gaya tekan. Pada zaman dahulu pembangunan jembatan pelengkung menggunakan material batu atau material yang lain yang tidak mampu menahan gaya tarik. Jembatan pelengkung juga cocok untuk struktur yang memiliki rasio beban mati dan hidup yang cukup besar $(\mathrm{ACl}$, 1996).

Jembatan pelengkung merupakan pelengkung yang menjadi struktur utama dalam menahan beban yang disalurkan dari deck ke kolom. Untuk itu peran pelengkung harus diperhatikan tinggi pelengkung dengan panjang pelengkung agar mampu memikul beban yang akan disalurkan ke pondasi. Dalam penelitian ini akan berfokus pada rise ratio antara tinggi pelengkung dengan 
Optimasi Geometri berdasarkan ... (Almulianur/ hal 146-157)

panjang pelengkung yang paling optimal dalam menerima beban. Untuk mendapatkan rise ratio yang paling optimum dilihat dari gaya-gaya dalam yang dihasilkan oleh jemabatan pelengkung dengan berbagai vaiasi interval rasio.

Pada kajian ini diharapkan bisa memberikan penjelasan tentang pemakaian geometri dengan medapatkan rasio yang paling optimum dengan bentang $150 \mathrm{~m}$ sehingga pada bentang yang sama bisa dijadikan referensi dalam penentuan geomteri pada jembatan pelengkung beton.

\section{METODE}

Optimasi geometri dilakukan dengan melihat gaya-gaya dalam yang terjadi pada pelengkung beton. Optimasi geometri dilakukan dengan memvariasikan rasio antara tinggi pelengkung dengan panjang pelengkung. Variasi rasio dilakukan antara 1 : 2 sampai $1: 8$ dengan interval perbedaan 0,25 . Optimasi geometri pelengkung dilakukan di softwere sap 2000 dengan mutu beton fc' $35 \mathrm{MPa}$ pada jembatan pelengkung beton dengan bentang $150 \mathrm{~m}$.

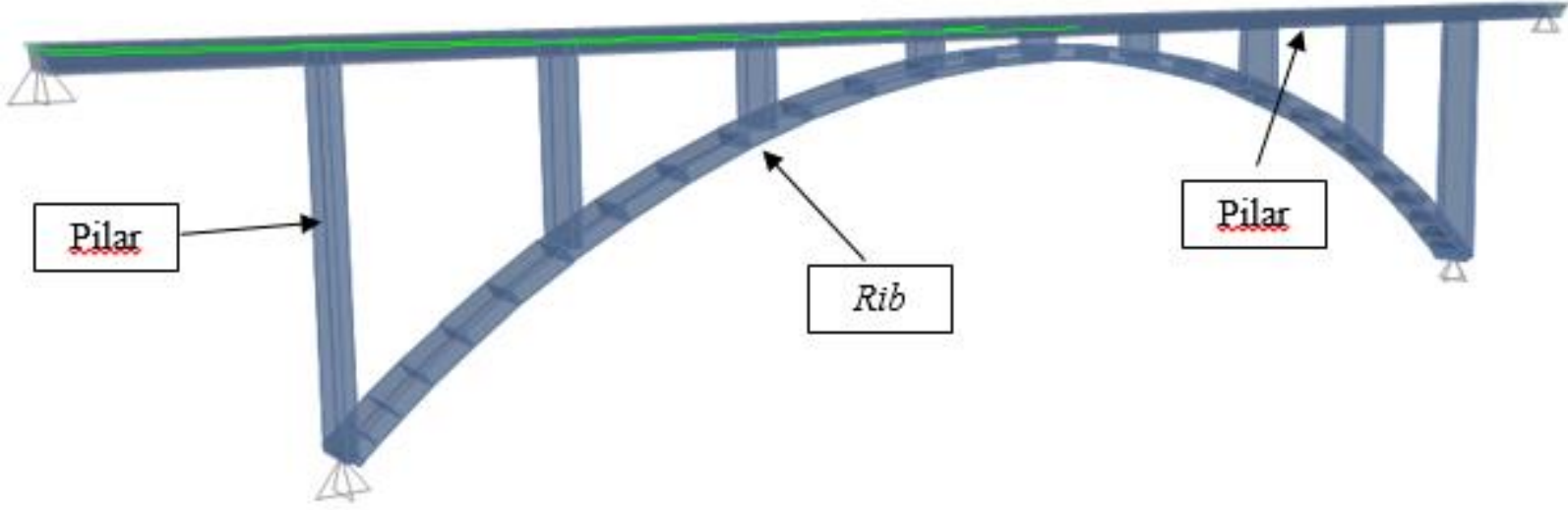

Gambar 1. Pemodelan jembatan pelengkung beton di sap 2000

Gambar 1 merupakan pemodelan jembatan pelengkung beton pada sap 2000 dengan dimensi penampang pilar tinggi $1 \mathrm{~m}$ dan lebar $5 \mathrm{~m}$, dimensi penampang pelengkung dengan tinggi $1.5 \mathrm{~m}$ dan lebar $5 \mathrm{~m}$, serta dimensi penampang dek bisa dilihat pada gambar 2.

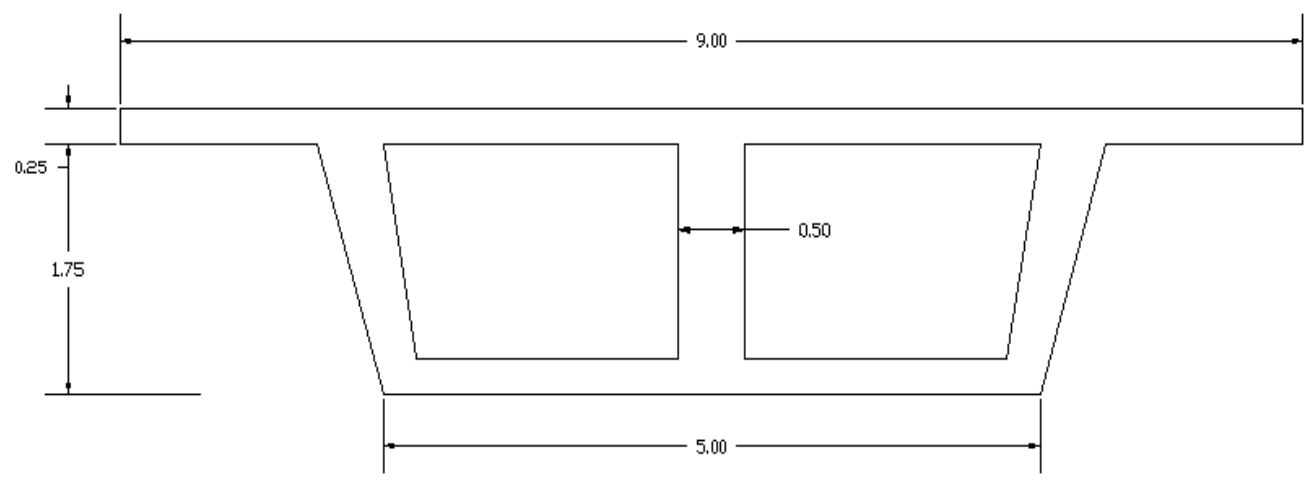

Gambar 2. Detail dek pada jembatan pelengkung beton 
Optimasi Geometri berdasarkan ... (Almulianur/ hal 146-157)

\section{HASIL DAN PEMBAHASAN}

Pembebanan untuk analisa struktur dan perancanagan struktrur mengacu pada SNI 1725 :2016 tentang analisa pembebanan pada jembatan jalan raya.

Beban mati meliputi berat sendiri struktur, berat sendiri deck beton jembatan dan beban mati akibat lapisan aspal beserta lapisan aspal tambahan akibat overlay diwaktu yang akan datang, ditambah genangan akibat air hujan jika sistem drainase tidak bekerja dengan baik a. Berat Sendiri Beton

Berat sendiri deck beton tergantung pada ketebalan beton yang digunakan. Ketebalan deck beton yang digunakan tergantung pada kebutuhan ketebalan berdasarkan analisis pembebanan terutama akibat beban lalu lintas khususnya beban truk.

Berat volume beton $=2320 \mathrm{~kg} / \mathrm{m}^{3}$

b. Berat Lapisan Aspal

Lapisan aspal pada jembatan ini merupakan lapisan permukaan pada deck jembatan.

Berat volume aspal $=2245 \mathrm{~kg} / \mathrm{m}^{3}$

Tabel 1. Beban mati pada jembatan

\begin{tabular}{|c|c|c|c|c|}
\hline No & Jenis & $\begin{array}{c}\text { Tebal } \\
(\mathrm{m})\end{array}$ & $\begin{array}{c}\text { Berat } \\
\left(\mathrm{kg} / \mathrm{m}^{3}\right) \\
\end{array}$ & $\begin{array}{c}\text { Beban } / \mathrm{m}^{2} \\
\left(\mathrm{~kg} / \mathrm{m}^{2}\right) \\
\end{array}$ \\
\hline 1 & $\begin{array}{l}\text { Lap, Aspal + } \\
\text { overlay }\end{array}$ & 0,05 & 2245 & 112,25 \\
\hline 2 & Air hujan & 0,05 & 1000 & 50,00 \\
\hline 3 & Deck beton & 0,20 & 2320 & 464,00 \\
\hline \multicolumn{3}{|c|}{ Beban mati pada jembatan $\left(\mathrm{kg} / \mathrm{m}^{2}\right)$} & $Q_{D}=$ & 626,25 \\
\hline \multicolumn{3}{|c|}{ Beban mati pada jembatan $\left(\mathrm{kN} / \mathrm{m}^{2}\right)$} & $Q_{D}=$ & 6,14 \\
\hline
\end{tabular}

Tabel 2. Beban mati tambahan pada jembatan

\begin{tabular}{llcccr}
\hline No & \multicolumn{1}{c}{ Jenis } & $\begin{array}{c}\text { Tebal } \\
(\mathbf{m})\end{array}$ & $\begin{array}{c}\text { Lebar } \\
(\mathbf{m})\end{array}$ & $\begin{array}{c}\text { Berat } \\
\left(\mathbf{k g} / \mathbf{m}^{3}\right)\end{array}$ & $\begin{array}{c}\text { Beban/m } \\
(\mathbf{k g} / \mathbf{m})\end{array}$ \\
\hline 1 & Spesi + pasangan & 0,10 & 1,00 & 2320 & 232,00 \\
2 & Pasir urug & 0,20 & 1,00 & 1755 & 351,00 \\
3 & Kerb & 0,30 & 0,25 & 2320 & 174,00 \\
4 & Railing 3 @ pipe $(73 \times 5,156)$ & 3 & 0,0011 & 7850 & 25,83 \\
Beban mati tambahan pada jembatan $(\mathrm{kg} / \mathrm{m})$ & & & $\mathrm{Q}_{\mathrm{AD}}=$ & 782,83 \\
Beban mati tambahan pada jembatan $(\mathrm{kN} / \mathrm{m})$ & & & $\mathrm{Q}_{\mathrm{AD}}=$ & 7,68 \\
\hline
\end{tabular}

Lokasi untuk pembebanan gaya gempa ditinjau pada daerah sungai Kampar di kabupaten Kampar Provinsi Riau. Adapun respon spectrum gempa untuk lokasi sungai Kampar yang diambil dari http://puskim.pu.go.id/Aplikasi/desain spektr a indonesia 2011/ bisa dilihat pada gambar 3.

Analisis beban gempa dilakukan berdasarkan SNI 2833: 2008 tentang Standar Perencanaan Ketahanan Gempa untuk Jembatan. 
Optimasi Geometri berdasarkan ... (Almulianur/ hal 146-157)

Beban gempa dianalisis dengan factor

Dikarenakan lokasi pembangunan jembatan berdasarkan pemilihan kecepatan angin dasar diasumsikan di kabupaten Kampar provinsi Riau maka begitu juga dengan lokasi beban gempa sebagai dasar pembuatan fungsi spektrum respon. modifikasi respon $(R)$ sebesar 2,5 dan faktor kepentingan 1,00. Variabel fungsi spektrum respon berdasarkan jenis tanah (siteclass) adalah sebagai berikut.

\begin{tabular}{lc} 
Tabel 3. Variabel fungsi spektrum respon \\
\hline Keterangan & $\begin{array}{c}\text { Tanah } \\
\text { Sedang }\end{array}$ \\
\hline PGA (g) & D \\
SS (g) & 0.158 \\
S1 (g) & 0.309 \\
CRS & 0.208 \\
CR1 & 0.971 \\
FPGA & 0.948 \\
FA & 1.484 \\
FV & 1.553 \\
PSA (g) & 1.984 \\
SMS (g) & 0.235 \\
SM1 (g) & 0.479 \\
SDS (g) & 0.413 \\
SD1 (g) & 0.32 \\
T0 (detik) & 0.275 \\
TS (detik) & 0.172 \\
\hline
\end{tabular}

Setelah mendapatkan Variabel fungsi Riau dengan mendapatkan Ss sebesar0.309 spektrum responyang didapatkan dari dan S1 sebesar 0.208 dengan kondisi tanah puskim sesuai lokasi sungai Kampar sedangmaka untuk membaut grafik respon kabupaten Kampar yang terletak di provinsi spektrum bisa dilihat pada gambar 3 . 
Optimasi Geometri berdasarkan ... (Almulianur/ hal 146-157)

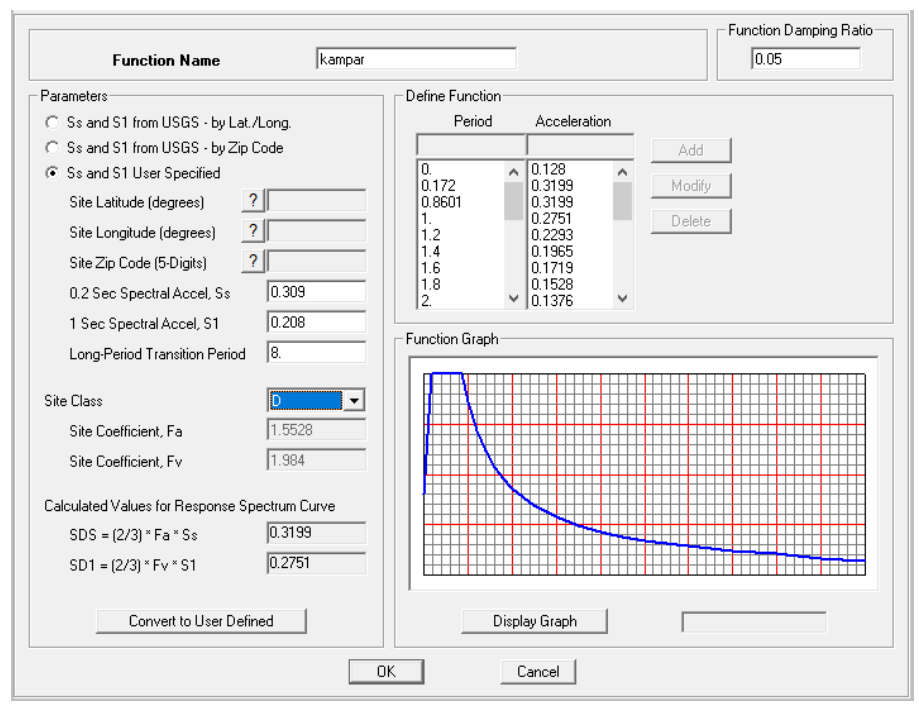

Gambar 3. Respon spektrum Kampar

Beban angin dianalisis berdasarkan metode yang dipakai didalam ASCE 7-10, Data angin didapatkan dari https://www,bps, go,id/statictable/2017/02/08/ 1960/kecepatan-angin-dan-kelembaban-distasiun-pengamatan-bmkg-2011-2015,html sebagai kecepatan angin dasar. Berdasarkan data angin yang merujuk pada website resmi BPS tersebut didapatkan lokasi dengan kecepatan angin untuk daerah kabupaten kampar. Oleh karena itu, kecepatan angin dasar yang digunakan analisis adalah kecepatan angin di daerah kabupaten Kampar.

Perhitungan beban angin adalah sebagai berikut,

$\begin{array}{lr}\text { Wind speed }(\mathrm{m} / \mathrm{s}) & 1.667 \\ \text { Wind speed }(\mathrm{mph}) & 117.5\end{array}$

(ASCE 7-10 memberikan ketentuan kecepatan angin dasar harus dipakai nilai 85 mph s,d, $150 \mathrm{mph}$, sehingga dipakai nilai rata-rata sebesar $117,5 \mathrm{mph}$ ) Exposuretype

D

Tabel 4. Faktor topografi $\left(\mathrm{K}_{\mathrm{zt}}\right)$ pada jembatan

\begin{tabular}{|c|c|}
\hline \multirow{2}{*}{$\operatorname{Span}(\mathrm{m})$} & Geometri \\
\hline & 150 \\
\hline Ratio & 5 \\
\hline
\end{tabular}

\begin{tabular}{lc}
\hline \multicolumn{1}{c}{ Span $(\mathrm{m})$} & Geometri \\
\cline { 2 - 2 } & 150 \\
\hline Height $(\mathrm{m})$ & 30 \\
\hline Height $(\mathrm{ft})$ & 98.4 \\
\hline Topographicalfactor, $\mathrm{K}_{\mathrm{zt}}$ & 1,425 \\
\hline
\end{tabular}

Gust factor

0,85

Directionally factor, $\mathrm{K}_{\mathrm{d}} \quad 0,85$

Tabel 5.Net force/shape factor $\left(\mathrm{C}_{\mathrm{f}}\right)$ pada jembatan

$\operatorname{Span}(\mathrm{m})$ Geometri 150

Ratio 5

Gross area $\left(\mathrm{m}^{2}\right)$ $4,656,978$

Soild area $\left(\mathrm{m}^{2}\right)$

$8,647,198$

Solid/Gross Area ratio 0,19

Net Force/Shape factor 1,80

Beban lalu lintas berda berdasarkan SNI 1725-2016 beban lajur lalu lintas terdiri dari beban terbagi rata (BTR) dan beban garis terpusat (BGT). Beban terbagi rata (BTR) untuk bentang lebih dari $30 \mathrm{~m}(\mathrm{~L}>30 \mathrm{~m})$ adalah sebagai berikut.

INERSIA, Vol. XIV No. 2, Desember 2018 
Optimasi Geometri berdasarkan ... (Almulianur/ hal 146-157)

\begin{tabular}{lc} 
Tabel 6. Beban lalu lintas pada jembatan \\
\hline Span $(\mathrm{m})$ & 150 \\
\hline BTR $\left(\mathrm{kN} / \mathrm{m}^{2}\right)$ & 5,40 \\
BGT $(\mathrm{kN} / \mathrm{m})$ & 49,00
\end{tabular}

Tabel 7. Koefisien perpanjangan pada material struktur

Beban temperatur dalam analisis ini diterapkan pada elemen-elemen struktur yang terdiri dari material beton dan baja. Material beton dan baja mempunyai karakter untuk berpotensi menjadi beban akibat efek temperatur karena masing-masing material mempunyai koefisien perpanjangan. Suhu yang harus diperhitungkan menurut SNI $1725-2016$ adalah $15^{\circ} \mathrm{C}$ s,d, $40^{\circ} \mathrm{C}$. Koefisien

\begin{tabular}{lc}
\multicolumn{1}{c}{ Material } & Koefisien Perpanjangan $\left({ }^{\circ} \mathrm{C}\right)$ \\
\hline Baja & 0,000012 \\
Beton $<30 \mathrm{MPa}$ & 0,000010 \\
Beton $>30 \mathrm{MPa}$ & 0,000011 \\
\hline
\end{tabular}
perpanjangan untuk material beton dan baja adalah sebagai berikut.

Pada kajian ini merupakan mencari geomtri pelengkung dengan variasi rasio antara tinggi pelengkung dan panjang pelengkung maka dapat dilihat dari gaya-gaya dalam yang terjadi pada jembatn pelengkung beton. Berikut merupakan hasil rekap gayagaya dalam yang terjadi pada jembatan pelengkung beton.

Tabel 8. Rekap NFD, SFD, BMD dan Weight bentang $150 \mathrm{~m}$.

\begin{tabular}{|c|c|c|c|c|c|c|}
\hline No & $r$ & $\begin{array}{c}f \\
\mathrm{~m}\end{array}$ & $\begin{array}{c}\text { NFD } \\
\text { kN }\end{array}$ & $\begin{array}{c}\text { SFD } \\
\text { kN }\end{array}$ & $\begin{array}{l}\text { BMD } \\
k N m\end{array}$ & $\begin{array}{c}\text { Weigth } \\
\text { kN } \\
\end{array}$ \\
\hline 1 & $1: 8.00$ & 25.00 & 3626.84 & 7161.71 & 16196.33 & 64097.69 \\
\hline 2 & $1: 7.75$ & 18.75 & 3444.48 & 7363.81 & 15837.05 & 64784.89 \\
\hline 3 & $1: 7.50$ & 19.35 & 5333.41 & 7015.27 & 25023.55 & 82019.3 \\
\hline 4 & $1: 7.25$ & 20.00 & 3380.85 & 7195.37 & 15698.99 & 64791.84 \\
\hline 5 & $1: 7.00$ & 20.69 & 3380.85 & 7195.37 & 15698.99 & 64791.84 \\
\hline 6 & $1: 6.75$ & 21.43 & 3037.62 & 7616.08 & 15058.76 & 65600.52 \\
\hline 7 & $1: 6.50$ & 22.22 & 2882.13 & 6765.92 & 14748.33 & 66058.52 \\
\hline 9 & $1: 6.00$ & 25.00 & 2612.77 & 7922.44 & 14155.87 & 67089.45 \\
\hline 10 & $1: 5.75$ & 26.09 & 2499.45 & 8040.50 & 13869.45 & 67679.59 \\
\hline 12 & $1: 5.25$ & 28.57 & 2193.31 & 6195.16 & 13294.40 & 69043.3 \\
\hline 13 & $1: 5.00$ & 30.00 & 2329.26 & 6915.09 & 14556.15 & 69814.36 \\
\hline 14 & $1: 4.75$ & 31.58 & 2298.08 & 7109.55 & 14863.73 & 70688.74 \\
\hline 15 & $1: 4.50$ & 33.33 & 2234.82 & 7186.55 & 14953.64 & 71675.35 \\
\hline 16 & $1: 4.25$ & 35.29 & 2269.00 & 7581.77 & 15852.89 & 72775.86 \\
\hline 17 & $1: 4.00$ & 37.50 & 2349.89 & 8134.56 & 17235.77 & 74024.28 \\
\hline 19 & $1: 3.50$ & 42.86 & 2644.98 & 9693.88 & 21159.70 & 77088.45 \\
\hline 20 & $1: 3.25$ & 46.15 & 2982.58 & 11114.19 & 24820.90 & 78977.31 \\
\hline 21 & $1: 3.00$ & 50.00 & 3502.32 & 13142.62 & 31480.06 & 81197.1 \\
\hline 22 & $1: 2.75$ & 54.55 & 4144.58 & 15923.87 & 47732.29 & 95506.81 \\
\hline 23 & $1: 2.50$ & 60.00 & 7238.30 & 25299.05 & 60998.05 & 106758.5 \\
\hline 24 & $1: 2.25$ & 66.67 & 17845.46 & 35448.24 & 107996.28 & 130192.7 \\
\hline
\end{tabular}

INERSIA, Vol. XIV No. 2, Desember 2018 
Optimasi Geometri berdasarkan ... (Almulianur/ hal 146-157)

\begin{tabular}{ccccccc}
\hline No & $\mathbf{r}$ & $\boldsymbol{f}$ & $\mathbf{N F D}$ & SFD & BMD & $\begin{array}{c}\text { Weigth } \\
\mathbf{m}\end{array}$ \\
\hline 25 & $1: 2.00$ & 75.00 & 32424.52 & 53250.77 & 299787.66 & 229845.9 \\
\hline
\end{tabular}

Dari tabel 8 didapatkan gaya-gaya dalam panjang jembatan anatara $1: 2$ sampai $1: 8$ yang terjadi pada jembatan pelengkung bisa dilihat pada gambar 4, gambar 5, beton. Untuk memudahkan dalam melihat gambar 6 gambar 7 dan gambar 8 .

pola gaya-gaya dalam yang terjadi dari rasio Gambar 4 merupakan polagaya axial yang pernbandingan tinggi pelengkung dan terjadi pada jembatan pelengkung beton.

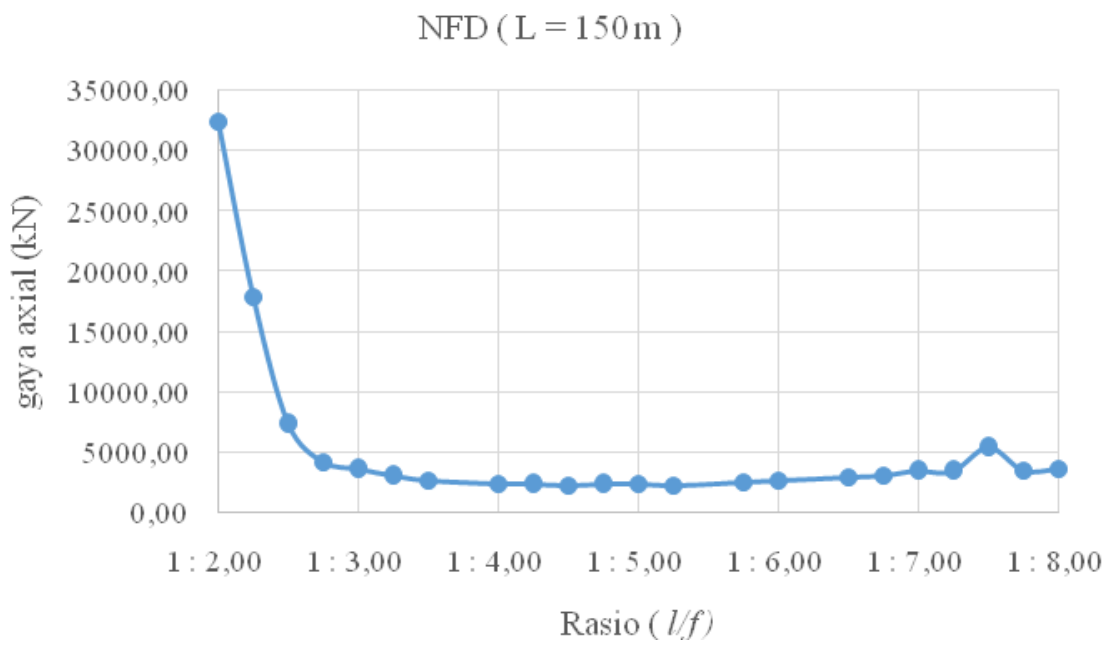

Gambar 4. Grafik NFD pada jembatan pelengkung beton bentang 150 m

Gambar 5 merupakan pola gaya geser yang terjadi pada jembatan pelengkung beton.

$\operatorname{SFD}(\mathrm{L}=150 \mathrm{~m})$

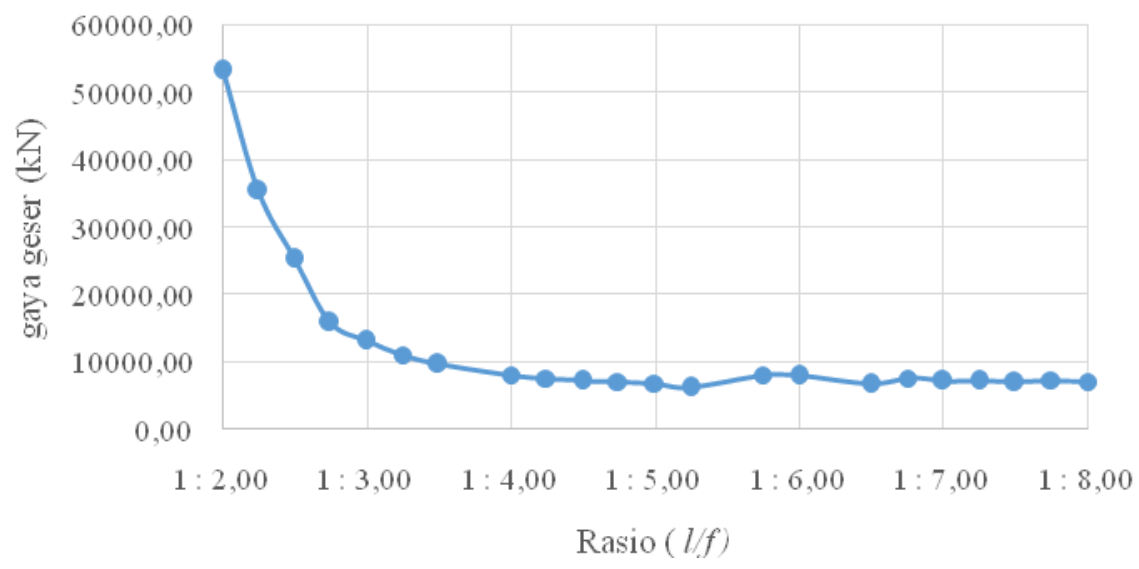

Gambar 5. SFD pada jembatan pelengkung beton bentang $150 \mathrm{~m}$

Untuk melihat pola banding moment diagram yang terjadi pada jembatan pelengkung jembatan pelengkung beton bisa dilihat pada gambar 6 . 
Optimasi Geometri berdasarkan ... (Almulianur/ hal 146-157)

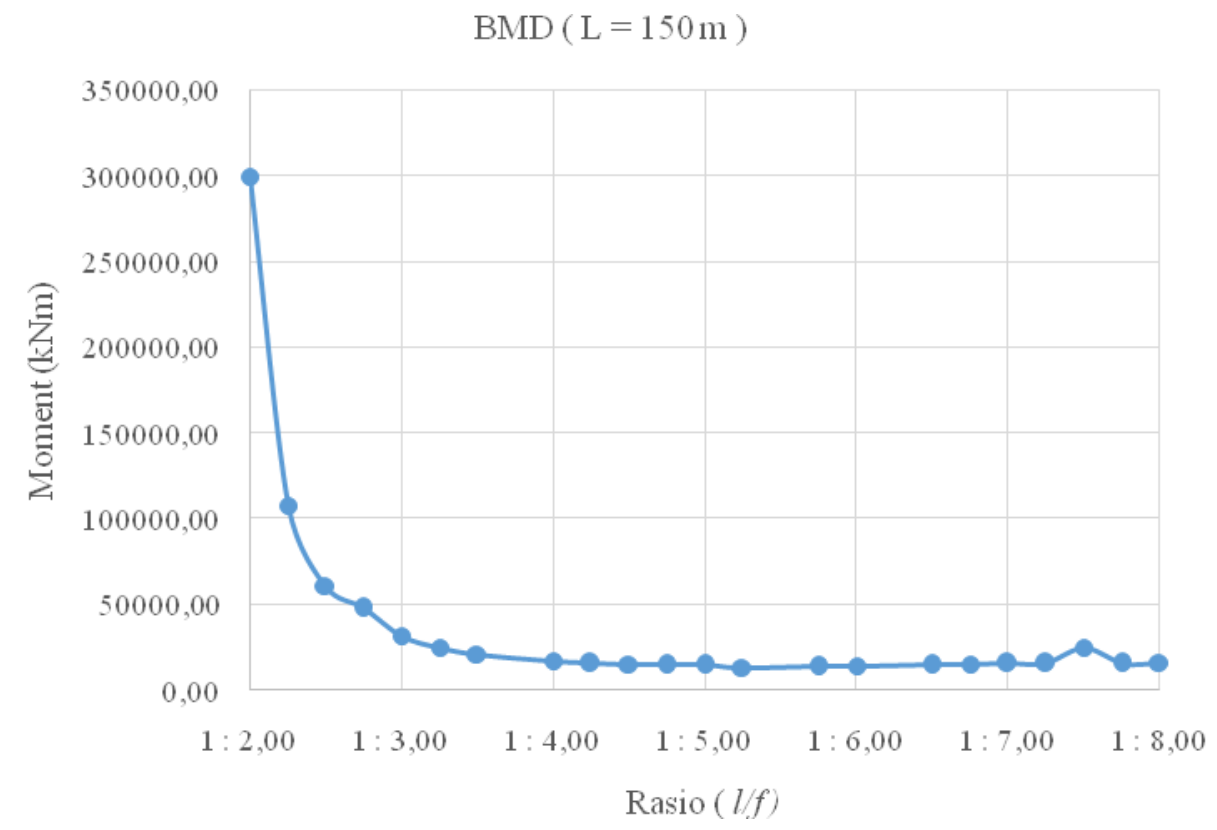

Gambar 6. BMD pada jembatan pelengkung beton bentang $150 \mathrm{~m}$

Dikarenakan pada penelitian ini mencari optimasi geometri yang terjadi pada jembatan pelengkung beton berdasarkan gaya-gaya dalam akan tetapi perlu dilihat juga optimasi geomtri berdasarkan berat yang terjadi pada jembatan pelengkung beton untuk mengetahui pola yang terjadiberdasarkan berat dengan memvariasi rasio, untuk itupola berdasarkan berat bisa dilihat pada gambar 7 .

$$
\text { Weight }(\mathrm{L}=150 \mathrm{~m})
$$

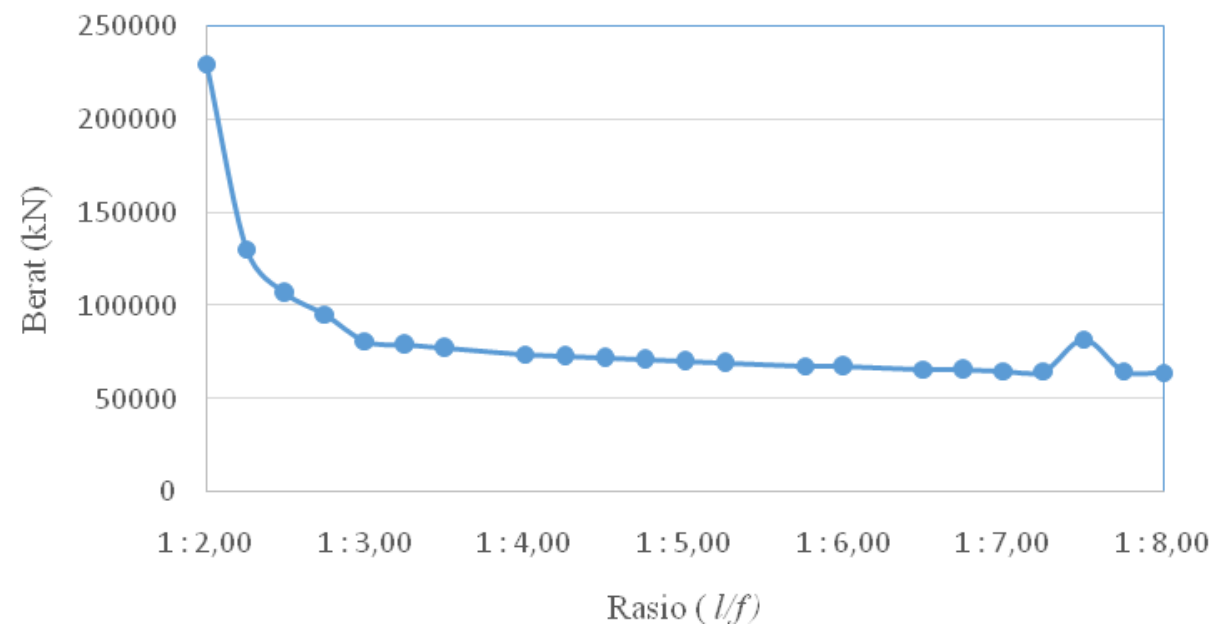

Gambar 7. Weight jembatan pelengkung beton bentang $150 \mathrm{~m}$

Untuk melihat optimasi rasio yang terjadi pada jembatan pelengkung beton pada bentang $150 \mathrm{~m}$ maka pola yang terjadi pada INERSIA, Vol. XIV No. 2, Desember 2018 gambar 4 , gambar 5 gambar 6 , dan gambar 7 digabungkan seperti yang terlihat pada gambar 8.Penggabungan dari pola yang 
Optimasi Geometri berdasarkan ... (Almulianur/ hal 146-157)

terjadi pada NFD, SFD, BMD dan berat penyekalaan bisa dilihat pada gambar 8 .

dilakukan penyekalaan 0 sampai 1. Pola

$\mathrm{NFD}, \mathrm{SFD}, \mathrm{BMD}$ dan berat $(\mathrm{L}=150 \mathrm{M})$

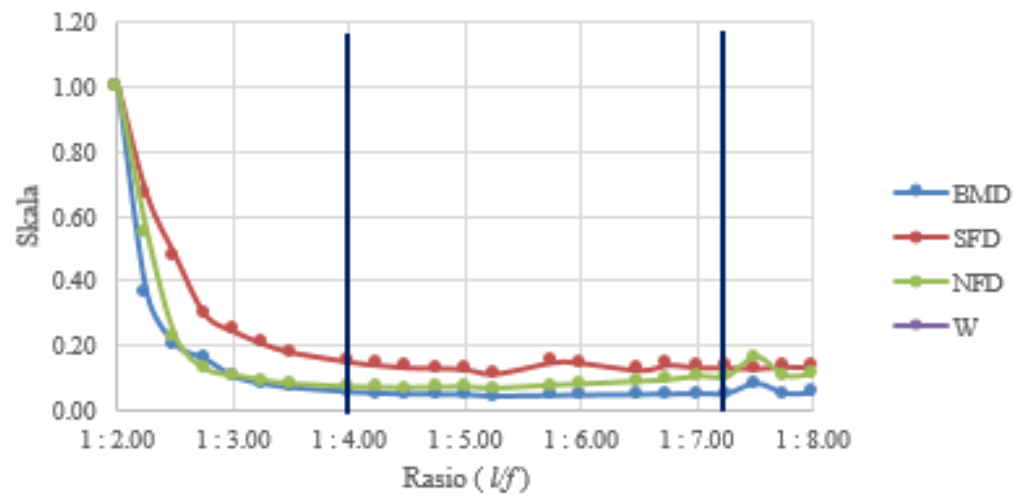

Gambar 8. NFD, SFD, BMD dan beratpada jembatan bentang $150 \mathrm{~m}$

Dari grafik yang ditunjukkan pada gambar 8 bisa dilihat garis yang mulai menunjukkan garis lurus dimulai dari $1: 4,00$ sampai 1 : 7,25 . Sehingga untuk bentang $150 \mathrm{~m}$ rasio yang paling optimum berada diantara 1 : 4,00 sampai $1: 7,25$.

Untuk melihat gaya-gaya dalam yang terjadi pada jembatan pelengkung baton yang dibahas seperti diatas bisa dipakai untuk geometri jembatan pelengkung beton maka perlu dilakukan tinjauan terhadap jembatan yang sudah dibangun di dunia, sehingga bisa memberikan penjelasan antara hasil gaya-gaya dan geometri existing bisa dipakai untuk geomtri jembatan pelengkung beton. Jembatan yang sudah ada dibangun diduniaakan dilihat rasio antara tinggi pelengkung dengan panjang pelengkung yang dipakai. Tabel 9 merupakan hasil rekap jembatan pelengkung yang ada di dunia yang bisa menjadi validasi untuk analisa optimasi geometri berdasarkan gaya-gaya dalam.

Tabel 9. Rekap jembatan existing di dunia ( Jason Salonga : 2013 )

\begin{tabular}{rlrlrrr}
\hline No & \multicolumn{1}{r}{ Nama Jembatan } & Tahun & Negara & Span & Rise & Ratio \\
\hline 1 & Bronte Creek & 1934 & Canada & 39.8 & 17.1 & 2.3 \\
2 & Big Creek & 1937 & USA & 54.1 & 23 & 2.4 \\
3 & Matsesta & 1938 & Russia & 63.6 & 23.6 & 2.7 \\
4 & Bixby Creek & 1932 & USA & 100.6 & 36.6 & 2.7 \\
5 & Dodan Nalah & 1995 & India & 40 & 14.5 & 2.8 \\
6 & Russian Gulch & 1939 & USA & 73.2 & 25.9 & 2.8 \\
7 & Maslenica & 1997 & Croatia & 200 & 65 & 3.1 \\
8 & Gmundertobel & 1909 & Switzerland & 80 & 26 & 3.1 \\
9 & Neckarburg & 1978 & Germany & 154 & 49.5 & 3.1 \\
10 & Niesenback & & Germany & 120 & 37.5 & 3.2 \\
11 & Stampfgraben & 2003 & Austria & 70 & 21 & 3.3 \\
12 & Hundwiler & 1991 & Swtzerland & 138.4 & 35.8 & 3.9 \\
13 & Broadway & 1932 & Canada & 54.7 & 13.9 & 3.9
\end{tabular}


Optimasi Geometri berdasarkan ... (Almulianur/ hal 146-157)

\begin{tabular}{|c|c|c|c|c|c|c|}
\hline No & Nama Jembatan & Tahun & Negara & Span & Rise & Ratio \\
\hline 14 & Wirrbachtal & 2002 & Germany & 100 & 25.3 & 4.0 \\
\hline 15 & Noslach & 1968 & Austria & 180 & 45 & 4.0 \\
\hline 16 & Lianlao & $?$ & Taiwan & 50 & 12.5 & 4.0 \\
\hline 17 & Rocky Creek & 1932 & USA & 68.6 & 17.1 & 4.0 \\
\hline 18 & Nanin & 1967 & Switzerland & 100.6 & 24.5 & 4.1 \\
\hline 19 & Maling & 1999 & Taiwan & 138 & 33 & 4.2 \\
\hline 20 & Ziggenbach & 1924 & Switzerland & 20 & 4.7 & 4.3 \\
\hline 21 & bloukrans & 1983 & South Aafrica & 272 & 62 & 4.4 \\
\hline 22 & Wertechtal & & Germany & 156 & 34 & 4.6 \\
\hline 23 & Caracas & 1953 & Venezuela & 151.8 & 32 & 4.7 \\
\hline 24 & Rhein & 1963 & Switzerland & 100 & 20.9 & 4.8 \\
\hline 25 & Siggenthal & 2000 & Switzerland & 117 & 24.4 & 4.8 \\
\hline 26 & Gelana Creek & 2011 & USA & 210 & 42.5 & 4.9 \\
\hline 27 & Wanxian - Yangtze & 1997 & China & 425 & 85 & 5.0 \\
\hline 28 & Houffalize & 1979 & Belgium & 162 & 32.4 & 5.0 \\
\hline 29 & Mazzocco & 2007 & Italy & 70 & 14 & 5.0 \\
\hline 30 & Fulton Road & 1932 & USA & 64 & 12.7 & 5.0 \\
\hline 31 & Argentobel & 1986 & Germany & 150 & 29 & 5.2 \\
\hline 32 & krk II & 1980 & Croatia & 244 & 47 & 5.2 \\
\hline 33 & Crooked River & 2000 & USA & 125 & 24 & 5.2 \\
\hline 34 & Bohlbach & 1932 & Switzerland & 14.4 & 2.7 & 5.3 \\
\hline 35 & rio parana & 1965 & Brazil & 290 & 53 & 5.5 \\
\hline 36 & Big Qualicium & 1996 & Canada & 132 & 24 & 5.5 \\
\hline 37 & Guiers & 2000 & France & 73.8 & 12.5 & 5.9 \\
\hline 38 & Modong Hangshui & 1999 & China & 180 & 30 & 6.0 \\
\hline 39 & Tiefetal & 1952 & Germany & 77.7 & 12.6 & 6.2 \\
\hline 40 & Schwandbach & 1933 & Switzerland & 37.4 & 6 & 6.2 \\
\hline 41 & Wunshuei & $?$ & Taiwan & 85 & 13.5 & 6.3 \\
\hline 42 & Hokowazu & 1974 & Japan & 170 & 26.5 & 6.4 \\
\hline 43 & Krk I & 1980 & Croatia & 390 & 60 & 6.5 \\
\hline 44 & sando & 1943 & Sweden & 264 & 40 & 6.6 \\
\hline 45 & Cetina & 2007 & Croatia & 140.3 & 20.6 & 6.8 \\
\hline 46 & Pag & 1968 & Croatia & 193 & 28 & 6.9 \\
\hline 47 & Salginatobel & 1930 & Switzerland & 90 & 13 & 6.9 \\
\hline 48 & Pitan & 1993 & Taiwan & 160 & 21.7 & 7.4 \\
\hline 49 & $\mathrm{Nan} \mathrm{Ke}$ & $?$ & Taiwan & 25 & 3.3 & 7.6 \\
\hline 50 & Gladesville & 1964 & Australia & 309 & 39 & 7.9 \\
\hline 51 & sibenik & 1966 & Croatia & 246 & 31 & 7.9 \\
\hline 52 & tensho & 2000 & Japan & 260 & 32.5 & 8.0 \\
\hline 53 & Wölkau & $?$ & Germany & 47.5 & 5.1 & 9.3 \\
\hline 54 & Elche de la Sierra & 1927 & Spain & 40 & 4 & 10.0 \\
\hline
\end{tabular}

INERSIA, Vol. XIV No. 2, Desember 2018 
Optimasi Geometri berdasarkan ... (Almulianur/ hal 146-157)

\begin{tabular}{rrrlrrr}
\hline No & \multicolumn{1}{c}{ Nama Jembatan } & Tahun & \multicolumn{1}{c}{ Negara } & \multicolumn{1}{c}{ Span } & Rise & Ratio \\
\hline 55 & infant henrique & 2003 & Portugal & 280 & 25 & 11.2 \\
56 & Jembatan Bajulmati & 2007 & Indonesia & 60 & 15 & \\
57 & Jembatan Jendral Sudirman & 1958 & Indonesia,Yogyakarta & 67.6 & 13.6 & \\
58 & Bunder Bridge & 2008 & Indonesia,Yogyakarta & 50 & 7 & \\
59 & Irung Petruk Bridge & 2005 & Indonesia,Yogyakarta & 110 & 9 \\
60 & Kelok 9 Bridge & 2012 & Sumtra Barat & 90 & & \\
\hline
\end{tabular}

Dari tabel 9 dapat dilihat raiso antara tinggi berdasarkan gaya-gaya dalam yang terjadi pelengkung dan bentang jmbatan pada berada pada rasio $1: 4$ sampai $1: 7,25 ; 2$ ) jembatan pelengkung beton yang sudah ada Untuk bisa memberikan perbandingan hasil di dunia akan di rekap pada Tabel 10 untuk antara gaya-gaya dalam yang terjadi pada melihat jumlah rasio perbandingan tinggi jembatan pelengkung beton dengan pelengkung dan bentang jembatan yang jembatan existing yang ada di dunia untuk dipakai di dunia.

\begin{tabular}{cc} 
Tabel 10. Rekap jumlah rise ratio \\
\hline Interval rasio & Jumlah \\
\hline $2.0-2.5$ & 2 \\
$2.6-3.0$ & 4 \\
$3.1-3.5$ & 5 \\
$3.6-4.0$ & 6 \\
$4.1-4.5$ & 4 \\
$4.6-5.0$ & 9 \\
$5.1-5.5$ & 6 \\
$5.6-6.0$ & 4 \\
$6.1-6.5$ & 5 \\
$6.6-7.0$ & 4 \\
$7.1-7.5$ & 1 \\
$7.6-8.0$ & 4 \\
$8.1-8.5$ & 0 \\
$8.6-9.0$ & 0 \\
$9.1-9.5$ & 1 \\
$9.6-1.0$ & 1 \\
\hline
\end{tabular}
rasio yang paling banyak dipakai tetap berada di interval rasio $1: 4$ sampai $1: 7,25$ sehingga untuk mendapatkan optimasi geometri bisa menggunakan gaya-gaya dalam serta berat yang terjadi pada pelengkung beton karena rasio gaya-gaya dalam dengan rasio existing jembatan di dunia masih dalam range yang sama.

\section{DAFTAR RUJUKAN}

American Concrete Institute, 1996, Analysis and Design of Reinforced Concrete Structures, Farmington: $\mathrm{ACl}$ Committee 343R-95.

Badan Standarisasi Nasional, 2008, SNI 2833:2008 Standar Perencanaan Ketahanan Gempa untuk Jembatan, Jakarta: Badan Standarisasi Nasional.

Dari tabel 10 setelah dilakukan rekap terhadap rasio pelengkung yang sering digunakan berada pada $1: 2,6$ sampai $1: 8$.

\section{SIMPULAN}

Dari hasil pembahasan di atas dapat di ambil kesimpulan seperti berikut: 1) optimasi geometri pada jembatan pelengkung

Badan Standarisasi Nasional, 2016, SNI 1725-2016 Standar Pembebanan untuk Jembatan, Jakarta: Badan Standarisasi Nasional.

Prihadi, W. R., \& Pratama, G. N. I. P. Konfigurasi Batang Pada Perancangan Rangka Atap Bambu. INERSIA, 12(2), 173-183. 
Optimasi Geometri berdasarkan ... (Almulianur/ hal 146-157)

Salonga, Jason. 2013. Comparative Study of the Proportions, Form, and Efficiency of Concrete Arch Bridge.kroasia : jurnal ASCE.

http://puskim.pu.go.id/Aplikasi/desain spektr a indonesia 2011/

https://www,bps,go,id/statictable/2017/02/08/ 1960/kecepatan-angin-dan kelembaban-di-stasiun-pengamatanbmkg-2011-2015, html 